\title{
Expression of The Transient Receptor Potential Channel 4 (TRPC4) Gene in Goats Naturally Exposed to Haemonchus contortus Infection
}

\author{
Michelle M. Corley ${ }^{1} \&$ J. R. Ward ${ }^{1}$ \\ ${ }^{1}$ Agriculture Research Station, Virginia State University, Virginia 23806, USA \\ Correspondence: Michelle M. Corley, Agriculture Research Station, Virginia State University, P.O. Box 9061, \\ Virginia 23806, USA. Tel: 1-804-524-6802/5890. E-mail: mcorley@vsu.edu
}

Received: June 15, 2013 Accepted: June 27, 2013 Online Published: August 15, 2013

doi:10.5539/jas.v5n9p212 URL: http://dx.doi.org/10.5539/jas.v5n9p212

\begin{abstract}
Expulsion of gastrointestinal nematodes (GIN) requires gut contractions and glycoprotein hyper-secretion for detachment from the gut wall. The Transient receptor potential cation channels (TRPC) facilitates contraction of smooth muscle. A mutation in the TRPC4 of mice significantly reduces contraction and motility of the intestine. Thus far, the correlation between TRPC4 and GIN infection has not been evaluated in goats or any other species. This study evaluated gene expression of TRPC4 in Haemonchus contortus exposed resistant goats. Goats that were naturally susceptible and resistant to Haemonchus contortus were sacrificed and intestinal tissues collected. From conserved regions of human, mouse, rat, and bovine TRPC4 gene alignments, oligonucleotide primers were generated using CLC Main Workbench bioinformatics software. The RT-PCR and quantitative real time pcr were performed using total RNA extracted from intestinal tissues. The expected 388bp cDNA product was amplified and sequenced. The goat TRPC4 showed 88 and $87 \%$ homology to rat and mouse and $98 \%, 92 \%, 91 \%$ and $90 \%$ homology to the bovine, horse, pig and human TRPC4 genes, respectively. The TRPC4 expression increased $(\mathrm{P}<0.05)$ in naturally susceptible goats. There were breed and gender effects $(\mathrm{P}<0.05)$ on TRPC4 expression. A strong $(\mathrm{P}<0.05)$ correlation was evident when the variables TRPC4 gene expression, clinical anemia, and parasite load were compared in goats. These data indicate that TRPC4 may aid in elucidation of the mechanism of action of the TRPC genes involved in gastrointestinal contraction and motility and their link to GIN infection.
\end{abstract}

Keywords: Haemonchus contortus, gastrointestinal motility, TRPC4, goat

\section{Introduction}

\subsection{Significance of the Problem}

Persistence in the development of control measures to target gastrointestinal nematode infection (GIN) in small ruminants remains a high priority for the small ruminant industry. Infection by Haemonchus contortus, a blood sucking gastrointestinal nematode (GIN), is the leading cause of economic losses in small ruminant production. Haemonchus contortus causes a disease known as haemonchosis in all domesticated ruminants (Asanji, 1988; Hogg et al., 2010; Schillhorn van Veen, 1978; van Dijk \& Morgan, 2006). Young animals are most susceptible, become heavily infected, and manifest anemia, hypoproteinemia and edema (Kaplan et al., 2004; Le Jambre, 1995). Treatment of GIN infection is controlled primarily by the use of anthelmintics which has lead to the development of drug resistance (Chandrawathani, Yusoff, Wan, Ham, \& Waller, 2004; Corley \& Jarmon, 2012; Terrill, Miller, Burke, Mosjidis, \& Kaplan, 2011). Focus has been geared towards identification of biomarkers that influence gut expulsion of GIN (Artis, 2006; Bancroft, Artis, Donaldson, Sypek, \& Grencis, 2000; Corley \& Jarmon, 2012; Khan et al., 2003; Perrigoue, Zaph, Guild, Du, \& Artis, 2009; Vallance et al., 1999). Very few have dealt with studies on biomarkers of gut expulsion of Haemonchus contortus in small ruminants (Corley \& Jarmon, 2012). Transient receptor potential (TRP) cation channels are involved in several cellular functions (Freichel et al., 2005; Gonzalez-Cobos \& Trebak, 2010). They are of interest because they are involved in contraction of smooth muscle (Gonzalez-Cobos \& Trebak, 2010; Ambudkar, 2009) and have been linked to many diseases (Nilius, Voets, \& Peters, 2005) including that of the digestive system (Holzer, 2011). As a result the TRPC family has been used for drug targets in neurogastroenterology (Boesmans, Owsianik, Tack, Voets, \& Vanden Berghe, 2011; Holzer, 2011). The TRPC channels function as calcium cation channels that cause membrane depolarization and entry of calcium into the cell, thereby resulting in smooth muscle contraction (Patel et al., 2010). Specifically, it has been shown that TRPC4 and TRPC6 deletions in mice, impairs intestinal 
motility and contractility (Tsvilovskyy et al., 2009). Goats are plagued with the gastrointestinal nematode Haemonchus contortus, that costs the small ruminant industry millions of dollars per annum in livestock loss and drug treatment (Corwin, 1997).

\subsection{Justification}

The ability of the intestine to expel worms is dependent on many factors, one of which is intestinal contractility (Artis, 2006; Hasnain et al., 2011). The TRPC4 in particular has been linked to gastrointestinal contraction and motility (Kim, So, \& Kim, 2006; Unno et al., 2006). Although the role of TRPC4 has been identified as crucial in intestinal contractility in mice, the TRPC4 gene has not been isolated in goats, nor evaluated in Haemonchus contortus infection. To date, the relationship between gene expression of TRPC4 and the response to GIN infection has not been assessed in goats or any other species. Moreover, the relationship between TRPC4 control over gastrointestinal motility and contractility and Haemonchus contortus infection in goats has not been investigated. Therefore the objectives of this study were to identify and characterize the TRPC4 gene of the goat and examine gene expression of TRPC4 in selected pasture exposed goats.

\section{Method}

\subsection{Experimental Animals and Haemonchus Contortus Detection}

Animals used in this study were Spanish and Myotonic goats. These animals were housed at VSU Randolph farm in accordance with institutional animal care and use guidelines. More than 100 Goats were screened for parasite load and clinical anemia status via fecal egg counts (FEC), packed cell volume (PCV) and FAMACHA eye color charts (FAM), and divided into susceptible and resistant groups accordingly. Our previously published work describe these procedures in detail (Corley \& Jarmon, 2012). The FEC, FAM and PCV data collected were analyzed using SAS version 9.1.3, (Cary, North Carolina). We determined that goats with $>2000$ eggs per gram of feces (EPG) with PCV $\leq 18$ were naturally susceptible and those goats with $>2000$ FEC with PCV $\geq 18$ were resistant. Animals were sacrificed and intestinal tissue samples collected and stored at $-80^{\circ} \mathrm{C}$ for nucleic analysis. Haemonchus contortus spp. was verified via nucleotide sequencing as previously published (M. Corley \& A. Jarmon, 2012). Nucleotide sequences were analyzed using sequence analysis software (NCBI-BLAST (Altschul, Gish, Miller, Myers, \& Lipman, 1990), CLC Main Workbench).

\subsection{Goat Intestinal Tissue Collection and Preparation}

Animals were sacrificed as previously published (Corley \& Jarmon, 2012) in accordance with national humane euthanasia guidelines. Intestinal including jejunal tissues were collected in sterile PBS and RNAlater (Invitrogen, $\mathrm{NY}$ ) and placed at $-80^{\circ} \mathrm{C}$ for further molecular analysis. Tissues were homogenized in sterile PBS, centrifuged at $10,000 \mathrm{~g}$ and supernatants collected for gene expression analysis.

\subsection{Total RNA Extraction from Goat Intestinal Tissue}

Total RNA was isolated from goat tissue samples previously stored at $-80^{\circ} \mathrm{C}$ using a modified RNA isolation procedure (Gauthier, Madison, \& Michel, 1997). Total RNA extraction procedures were performed according to previously published methods (Corley \& Jarmon, 2012). Concentration and purity of total RNA were measured using a Nanodrop ND-1000 spectrophotometer (Thermoscientific). The RNA was stored at $-80^{\circ} \mathrm{C}$ for later use in RT-PCR and qRT-PCR.

\subsection{Reverse Transcriptase PCR (RT-PCR) of Goat TRPC4}

Oligonucleotide primers were designed from mRNA of the bovine human, horse, pig, mouse and rat TRPC4 nucleotide sequences using the bioinformatics software, CLC Main Workbench (http://www.clcbio.com). Primers and target regions used for isolation of the goat TRPC4 gene are given in Table 1. The RT-PCR was conducted using the recommended protocol of the Verso 1-step RT-PCR kit (Thermo Scientific). Modified thermocyling conditions for 40 cycles were as follows: $50^{\circ} \mathrm{C} 15$ minutes, $95^{\circ} \mathrm{C}, 2$ minutes (initial denaturation), $95^{\circ} \mathrm{C}, 30$ secs, $55^{\circ} \mathrm{C}, 1$ minute, $72^{\circ} \mathrm{C}, 1$ minute repeated 39 times and a final extension at $72^{\circ} \mathrm{C}$ for 5 minutes. The target TRPC4 cDNA was visualized by $1.5 \%$ agarose gel electrophoresis and a UGenius UV gel documentation system (SynGene, Fredericksburg, MD) equipped with a high resolution CCD camera.

\subsection{Nucleotide Sequencing of Goat TRPC4 cDNA}

For TRPC4 nucleotide sequencing, the cDNA (388bp) products were cut out and purified from agarose gels (Qiagen and Bio-Rad). The purity and concentration of gel purified cDNA was measured and prepared for nucleotide sequencing per commercial instructions. Samples were sent for sequencing at GeneWiz (South Plainfield, New Jersey). Raw nucleotide sequences were analyzed using sequence analysis software 
(NCBI-BLAST, CLC Main Workbench). Subsequently, qRT-PCR analysis was conducted to determine gene expression of goat TRPC4 cDNA.

\subsection{Measurement of Goat TRPC4 Gene Expression}

Gene expression of TRPC4 in goat intestinal tissues was measured using qRT-PCR. The analytical parameters were as previously published (M. Corley \& A. Jarmon, 2012). In brief, the analysis was conducted using the iScript One Step RT-PCR kit with SYBR Green (BioRad). For each reaction 100ng of total RNA was used. The Actin gene was used as an internal standard for relative quantitative analysis of TRPC4 gene expression.

\subsection{Statistical Analysis}

Relative fold quantitation data were analyzed using the General Linear Model procedure of SAS. Trial differences $(\mathrm{n}=3)$ were accounted for by using a Randomized Complete Block Design. Means were considered significant at $\mathrm{P}<0.05$. Pearson Correlation Coefficient analysis was performed to compare variables measured (FEC, FAMACHA, PCV, TRPC4).

\section{Results}

Haemonchus contortus sp. verification was performed by direct gene detection (M. Corley \& A. Jarmon, 2012). Goats in susceptible and resistant groups were significantly $(\mathrm{P}<0.05)$ different, indicating that the criteria used to determine susceptibility and resistance to Haemonchus contortus was valid. After RNA isolation from the goat tissue, RT-PCR was performed. Agarose gel electrophoresis was performed to visualize the expected 388bp goat TRPC4 cDNA (Figure 1). The goat TRPC4 cDNA was sequenced and aligned to the human, horse, bovine, pig, mouse and rat TRPC4 genes to identify sequence similarities (Figure 2). The goat TRPC4 amino acid sequence was aligned with the human, horse, bovine, Pig, mouse and rat TRPC4 AA sequences (Figure 3). The Basic Local Alignment Search Tool (BLAST) (Altschul et al., 1990, 1997) of the goat TRPC4 showed 98\%, 92\%, 91\% and $90 \%$ nucleotide sequence homology to the bovine, horse, pig and human TRPC4 genes respectively and 88 and $87 \%$ homology to rat and mouse TRPC4 respectively (Figure 2). In the partial amino acid sequence alignment of goat TRPC4, showed that on the translational level, bovine and goat TRPC4 differed only by $1 \%$ among the bovine, human horse mouse rat and the pig differed by 2\% (Figure 3). Gene expression of TRPC4 was lower $(\mathrm{P}<0.05)$ in Haemonchus contortus resistant goats (Figure 4). Myotonic goats expressed more $(\mathrm{P}<0.05)$ TRPC4 than Spanish goats (Figure 5). The TRPC4 was also upregulated $(\mathrm{P}<0.05)$ in male goats compared to female goats (Figure 6). There was no significant difference in TRPC4 gene expression relative to age, but older goats (5-7 years old) tended to express more TRPC4 than younger goats (1-5 years old) (Figure 7). Overall, there was a strong positive $(\mathrm{P}<0.05)$ correlation between TRPC4 gene expression and FAMACHA eye color chart scores and FEC, and a strong negative correlation $(\mathrm{P}<0.05)$ with $\mathrm{PCV}$ in goats.

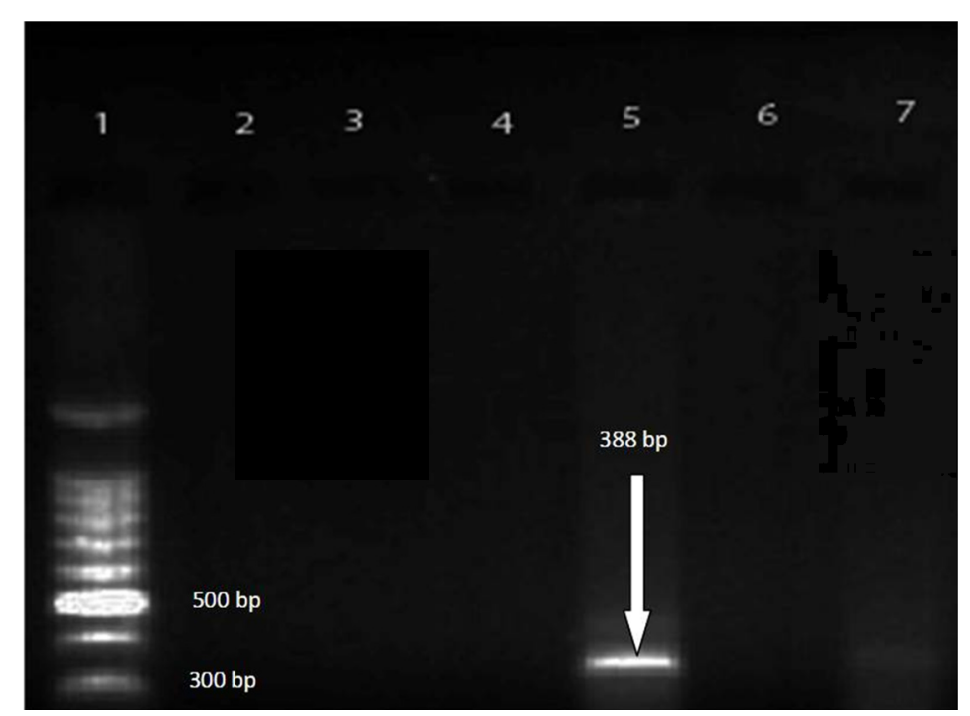

Figure 1. Agarose Gel Electrophoresis of Goat TRPC4 cDNA after Reverse Transcriptase PCR

Gel electrophoresis of Goat TRPC4 cDNA. The gel is $1.5 \%$ agarose with $0.05 \mathrm{mg} / \mathrm{ml}$ ethidium bromide. Lane 1=Molecular Weight Marker, Lane $5=$ Goat TRPC4 cDNA (388 bp). 
Table1. Primers and Target Regions used for isolation of the goat TRPC4 gene from goat tissue

\begin{tabular}{lllll}
\hline Accession No. & Primer name & Conserved Primer sequence & Target Region & Fragment Length (bp) \\
\hline NM174478 & Forward & CCCCACGAGGTCCGCTGTAA & $795-814$ & 388 \\
NM016179 & Reverse & GCCATTAAGTACCGTCAGAAA & 1163-1182 (Rev-comp) & \\
NM001145868 & & & & \\
XM001495912 & & & & \\
NM016984 & & & & \\
NM080396 & & & & \\
\hline
\end{tabular}

Table showing a summary of the Accession numbers of the TRPC4 genes used for nucleotide alignments and design of oligonucleotide primers from conserved regions among the species (human, mouse, rat, pig, horse, cattle). The CLC Main Workbench Bioinformatics software was used to generate primers.

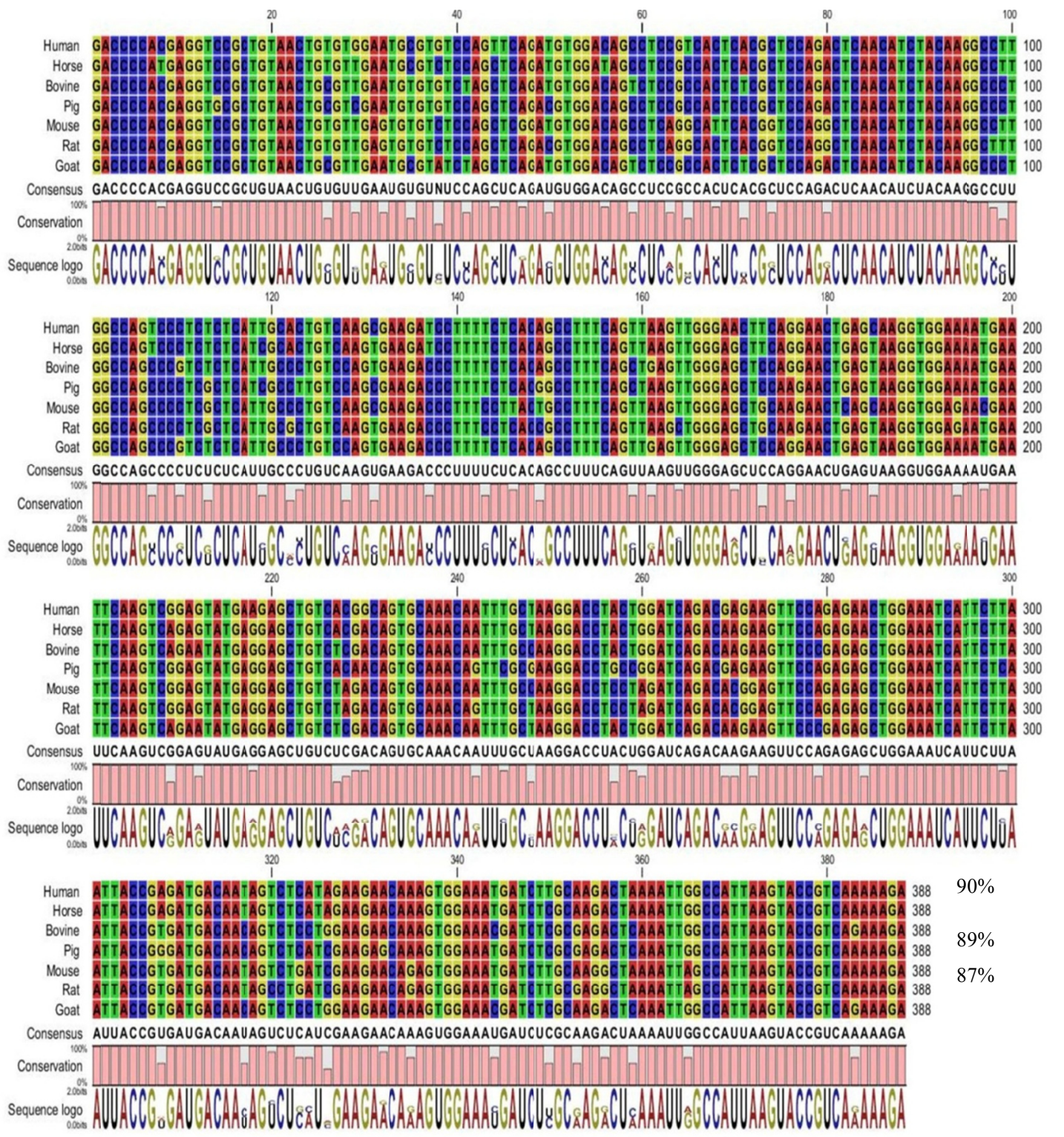

Figure 2. Nucleotide sequence alignment showing homology of goat, human, horse, bovine, pig, mouse and rat TRPC4 genes

Nucleotide sequence alignment of partial goat TRPC4 gene is shown. Alignment is shown to validate the conserved regions used to design the cross species oligonucleotide primers. Generated using CLC Main 
Workbench Bioinformatics software Percentage represents the degree of homology among partial nucleotide sequences of the TRPC4 genes.

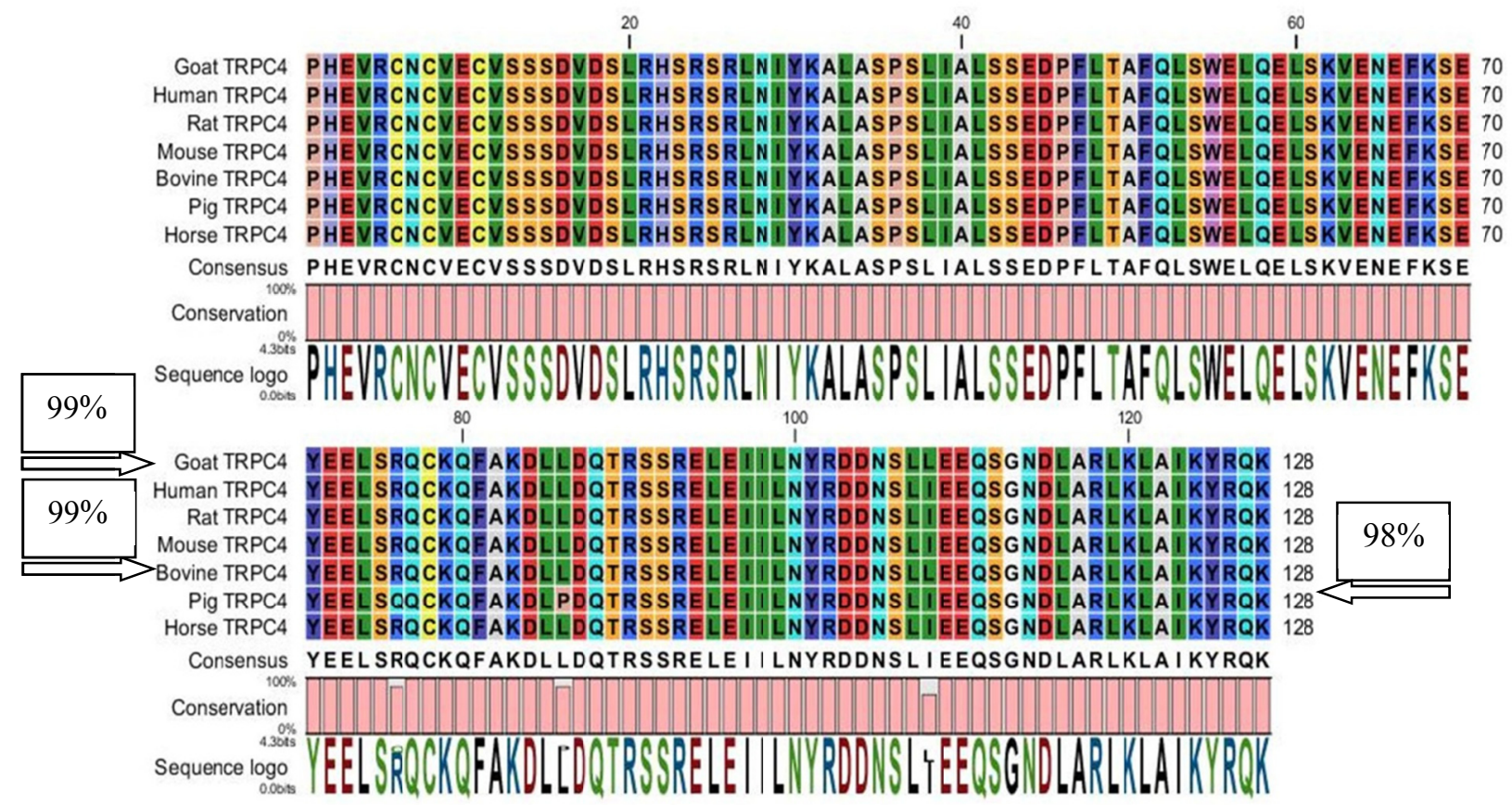

Figure 3. Amino acid alignment of translated goat, human, horse, bovine, pig, mouse and rat TRPC4

Amino acid translated sequence alignment of partial goat TRPC4 gene is shown. Alignment is shown to validate the conserved regions used to design the cross species oligonucleotide primers. Degeneracy lends to a greater amino acid sequence homology of the partial TRPC4 genes. Generated using CLC Main Workbench Bioinformatics softwarePercentage represents the degree of homology among partial amino acid sequences of the TRPC4 genes.

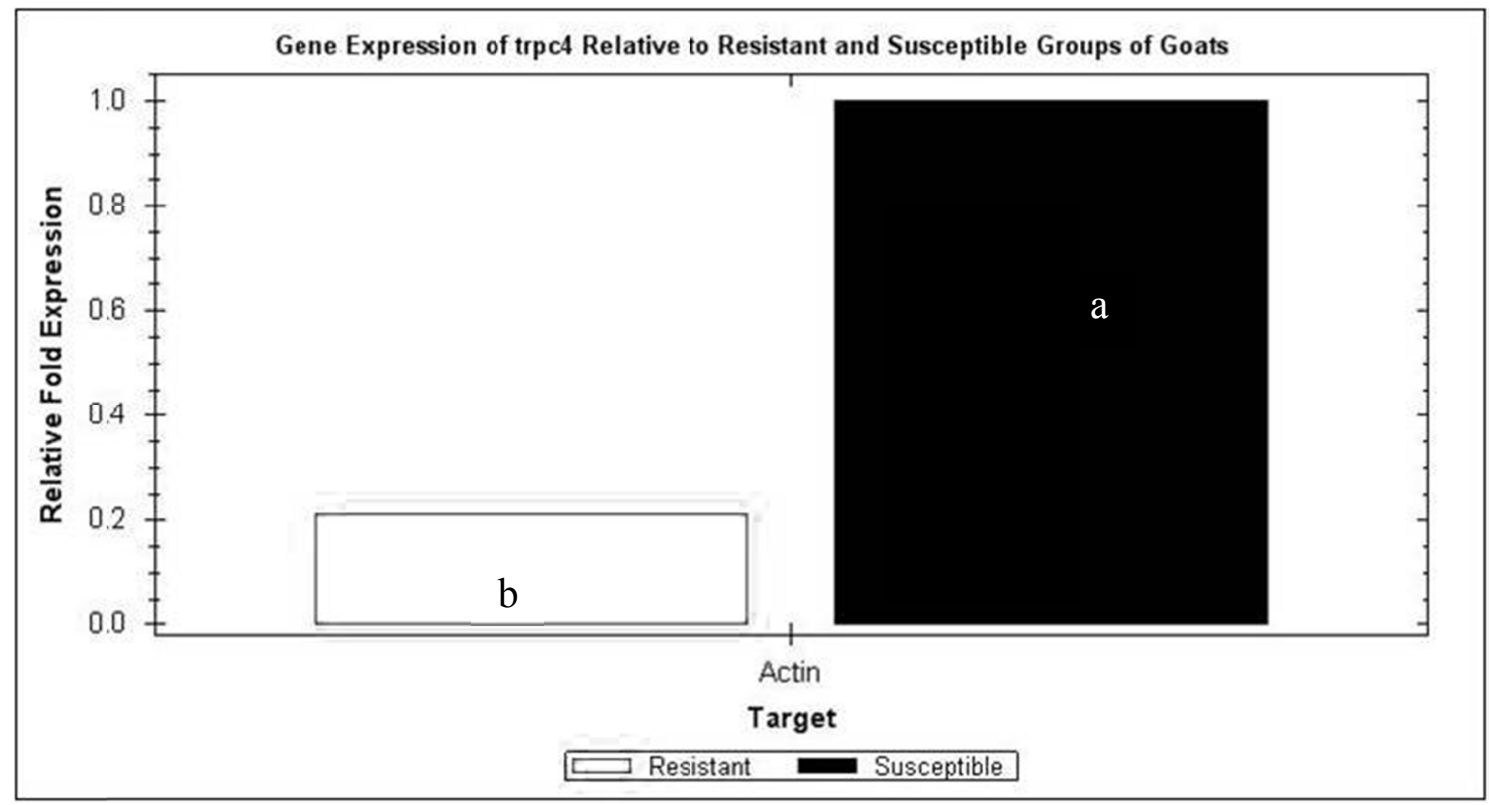

Figure 4. Gene expression of TRPC4 in the intestine in resistant and susceptible groups of goats

Relative fold expression of TRPC4 gene in resistant and susceptible goats as measured by qRT-PCR. $\mathrm{ab}$, Means with different letters differ $(\mathrm{P}<0.05)$. 


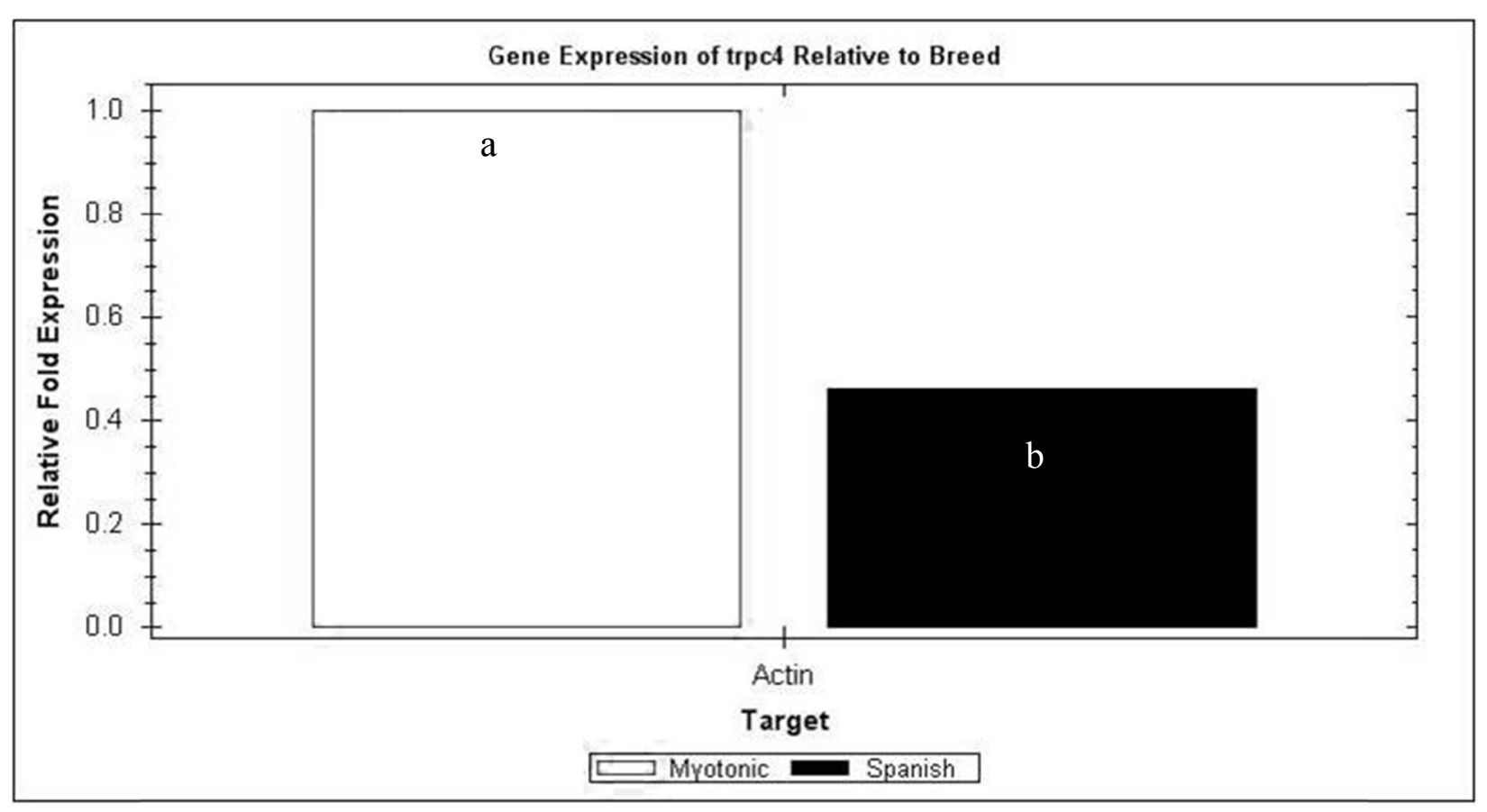

Figure 5. Gene expression of TRPC4 in the intestine of goats naturally exposed to Haemonchus contortus as influenced by breed

Relative fold expression of TRPC4 gene in Spanish and Myotonic goats as measured by qRT-PCR. $\mathrm{ab}$, Means with different letters differ $(\mathrm{P}<0.05)$.

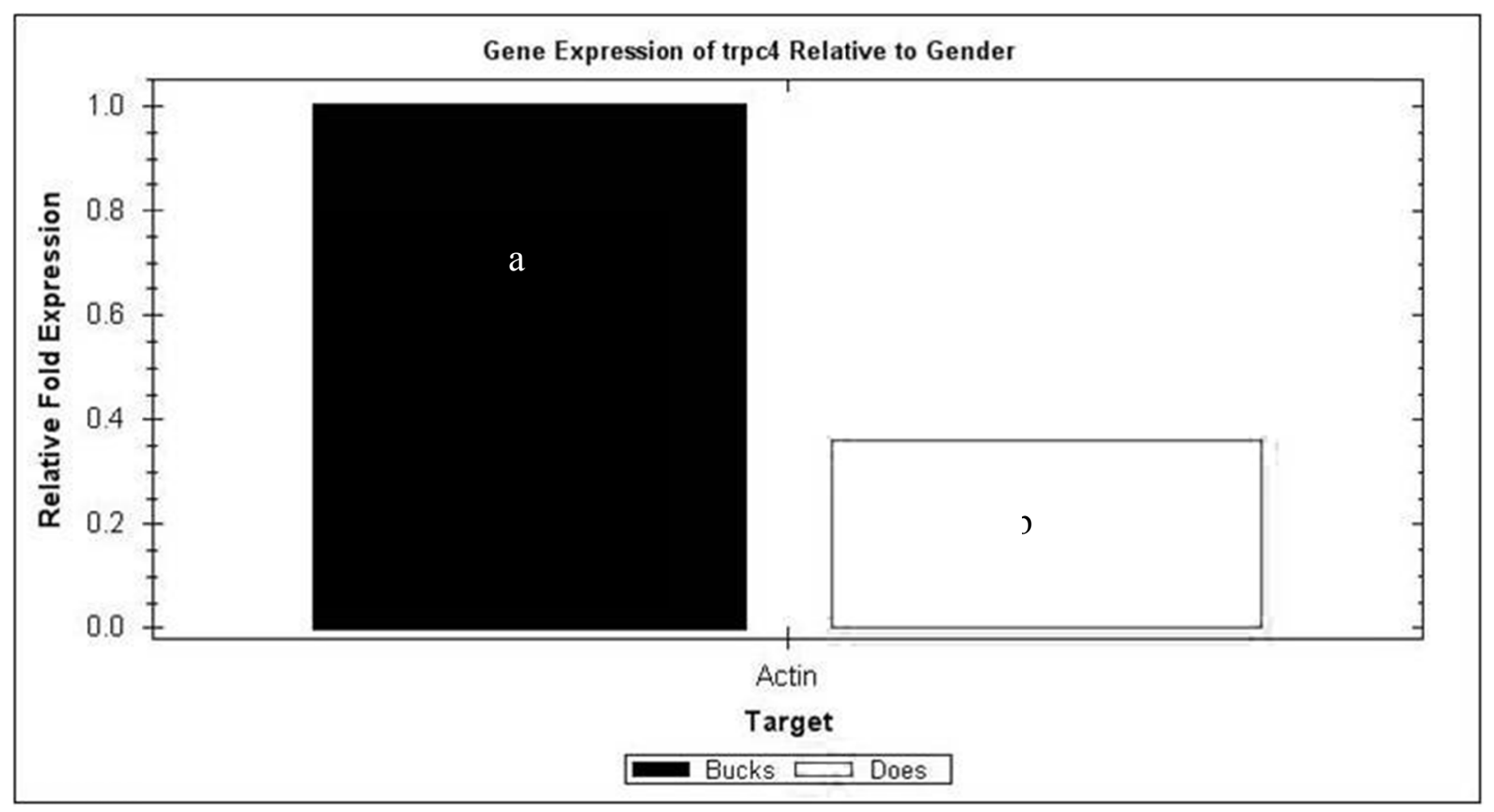

Figure 6. Gene expression of TRPC4 in the intestine of goats naturally exposed to Haemonchus contortus as influenced by gender

Relative fold expression of TRPC4 gene in male and female goats as measured by qRT-PCR. $\mathrm{ab}$, Means with different letters differ $(\mathrm{P}<0.05)$. 


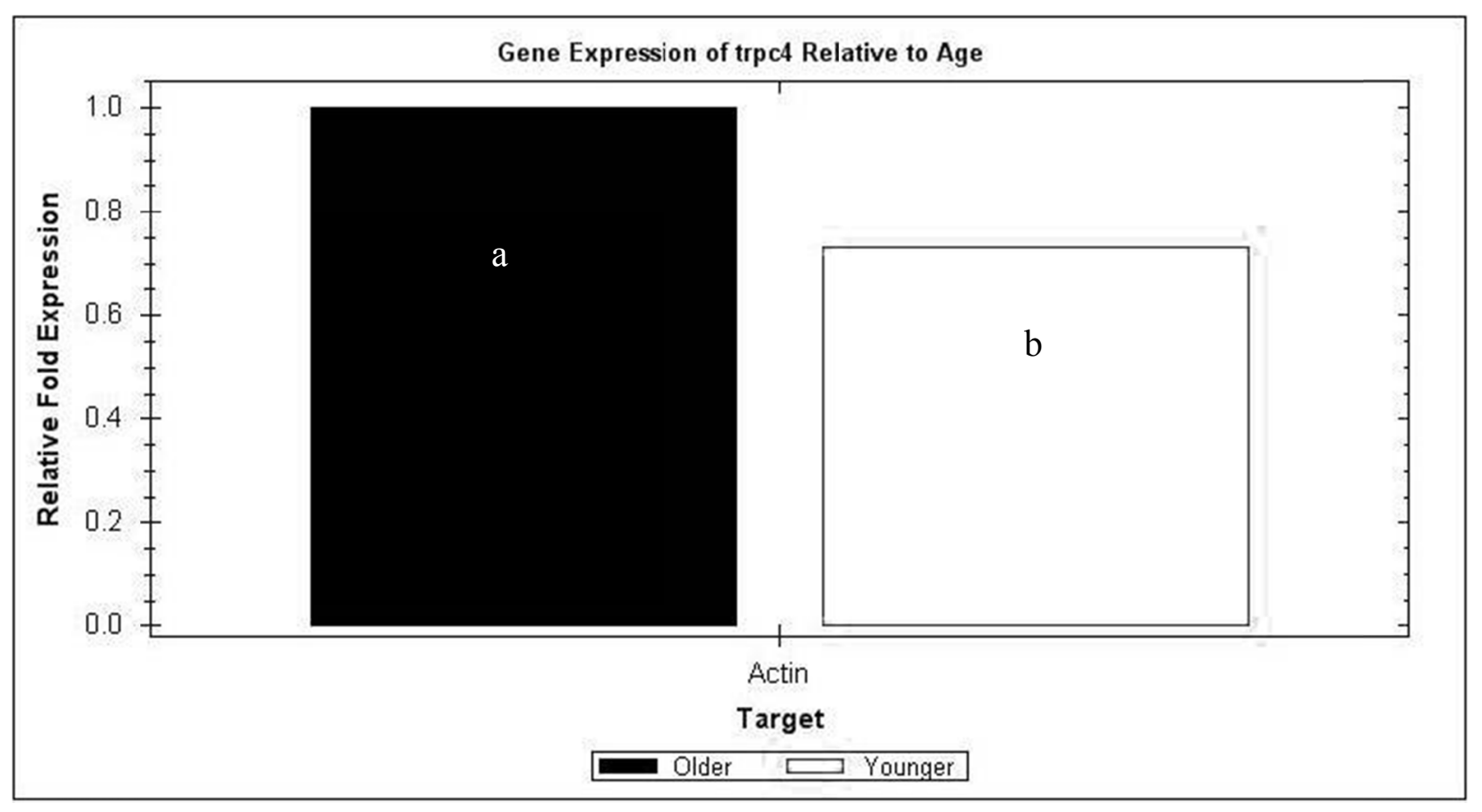

Figure 7. Gene expression of TRPC4 in the intestine of goats naturally exposed to Haemonchus contortus as influenced by age

Relative fold expression of TRPC4 gene in goats of different ages (older $=3-5$ yrs old, younger $=1-3$ yr old) as measured by qRT-PCR.

$\mathrm{ab}$, Means with different letters differ $(\mathrm{P}<0.05)$.

\section{Discussion}

The ability of the intestine to expel worms is dependent on many factors, one of which is intestinal contractility. Although the role of TRPC4 (Tsvilovskyy et al., 2009) and TRPC6 (Tsvilovskyy et al., 2009 have been identified as crucial in intestinal contractility in mice, no sequence data for the TRPC4 nor the TRPC6 gene had been reported in goats, nor evaluated in Haemonchus contortus infection. We were able to isolate a partial sequence of the goat (GenBAnk Accession No. JX962344) TRPC4 and studies are under way with TRPC6. Based on previous studies TRPC4 gene knockout mice exhibited impaired gastrointestinal motility and contractility (Tsvilovskyy et al., 2009). This led to testing the hypothesis that goats showing resistance to Haemonchus contortus would upregulate gene expression of TRPC4. The rationale was that since TRPC4 is involved in intestinal contractility and motility then goats should have more motility and contractility during infection by Haemonchus contortus and therefore be prone to more gut expulsion of the nematodes. However, these data showed that TRPC4 was down regulated in the resistant group of goats. This response is complex but may be explained by other studies that have demonstrated that TRPC4 protein is down regulated in smooth muscle as a protective mechanism in response to muscle stretch (Lindsey, Tribe, \& Songu-Mize, 2008). This down regulation of TRPC4 was demonstrated in aortic and mesenteric smooth muscle cells isolated from male Sprague-Dawley rats. The TRPC4 expression was decreased after 5 hour stretch and remained suppressed through a $24 \mathrm{~h}$ stretch and, recovered after removal of the stretch stimulus within 2 hours (Lindsey et al., 2008). In this study the down regulation of TRPC4 gene expression in the resistant groups of goats may have been a result of this protective mechanism existing in the intestine after Haemonchus contortus infection. This hypothesis is yet to be tested, as it has not been demonstrated in the intestine, particularly in goats with Haemonchus contortus infection. The mode of action of these genes in GIN infection is a more complex paradigm. Myotonic goats expressed more TRPC4 than Spanish goats. This supports the inference that TRPC4 is upregulated in goats more susceptible to Haemonchus contortus infection as this was the case in the susceptible group of goats. On the other hand, our previous studies have shown that interleukin 13, another biomarker of GIN resistance (Artis, 2006; Grencis \& Bancroft, 2004), involved in gut expulsion of nematodes (Artis, 2006), was down regulated in myotonic goats (M. M. Corley \& A. A. Jarmon, 2012). This makes a strong case that 
TRPC4 is upregulated in more Haemonchus contortus susceptible goats. The TRPC4 was also upregulated in male goats compared to female goats. This response is logical, as it has been previously demonstrated that male goats are more susceptible to Haemonchus contortus infection than female goats (M. Corley \& A. Jarmon, 2012). There was no significant difference in TRPC4 gene expression relative to age, but older goats (5-7 years old) tended to express more TRPC4 than younger goats (1-5 years old). This response could be explained by the fact that older goats have a weaker immune system than younger but a closer look would have to be made by widening the age gap in different groups of goats to see any significant effect in age groups for TRPC4 gene expression. Overall, there was a strong positive correlation between TRPC4 gene expression and FAMACHA eye color chart scores and FEC, and a strong negative correlation with PCV in goats. An increase in TRPC4 gene expression correlated with a high parasite load and anemia. On the other hand TRPC4 was down regulated in goats that were not experiencing anemia. This indicated that TRPC4 is upregulated in goats more susceptible to Haemonchus contortus infection. These data indicate thatTRPC4 gene expression correlates with susceptibility in goats pasture exposed to Haemonchus contortus. This would indicate that TRPC4 may be a potential biomarker for susceptibility rather than resistance to Haemonchus contortus infection in goats.

\section{Conclusion}

The results of this study indicated that the cross species oligonucleotide primers designed from the conserved regions of the TRPC4 genes can successfully be used to isolate a partial sequence of the goat TRPC4, from intestinal tissue samples, and used as a biomarker to evaluate gene expression in response to Haemonchus contortus infection in goats. Based on our findings, the TRPC4 gene could potentially be studied as a genetic marker for susceptibility to GIN infection, specifically Haemonchus contortus and could potentially be targeted for drug development in the treatment of GIN infection.

\section{Acknowledgements}

The authors would like to thank the Virginia State University Animal care staff (Amanda Miller, and Roslyn Stein). This research was funded by USDA-EVANS ALLEN grant at the Virginia State University Agricultural Research Station, Petersburg Virginia 23806. Journal Article Series No. 305

\section{References}

Altschul, S. F., Gish, W., Miller, W., Myers, E. W., \& Lipman, D. J. (1990). Basic local alignment search tool. J Mol Biol, 215(3), 403-410.

Altschul, S. F., Madden, T. L., Schäffer, A. A., Zhang, J., Zhang, Z., Miller, W., \& Lipman, D. J. (1997). Gapped BLAST and PSI-BLAST: a new generation of protein database search programs. Nucleic Acids Res, 25(17), 3389-3402.

Ambudkar, I. S. (2009). Unraveling smooth muscle contraction: the TRP link. Gastroenterology, 137(4), 1211-1214.

Artis, D. (2006). New weapons in the war on worms: identification of putative mechanisms of immune-mediated expulsion of gastrointestinal nematodes. Int $J$ Parasitol, 36(6), 723-733. http://dx.doi.org/10.1016/j.jpara.2006.02.011

Asanji, M. F. (1988). Haemonchosis in sheep and goats in Sierra Leone. J Helminthol, 62(3), 243-249. http://dx.doi.org/10.1017/S0022149X00011597

Bancroft, A. J., Artis, D., Donaldson, D. D., Sypek, J. P., \& Grencis, R. K. (2000). Gastrointestinal nematode expulsion in IL-4 knockout mice is IL-13 dependent. Eur $J$ Immunol, 30(7), 2083-2091. http://dx.doi.org/10.1002/1521-4141(200007)30:7<2083::AID-IMMU2083>3.0.CO;2-3

Boesmans, W., Owsianik, G., Tack, J., Voets, T., \& Vanden Berghe, P. (2011). TRP channels in neurogastroenterology: opportunities for therapeutic intervention. $\mathrm{Br} J$ Pharmacol, 162(1), 18-37. http://dx.doi.org/10.1111/j.1476-5381.2010.01009.x

Chandrawathani, P., Yusoff, N., Wan, L. C., Ham, A., \& Waller, P. J. (2004). Total anthelmintic failure to control nematode parasites of small ruminants on government breeding farms in Sabah, East Malaysia. Vet Res Commun, 28(6), 479-489. http://dx.doi.org/10.1023/B:VERC.0000040240.69004.dc

Corley, M. M., \& Jarmon, A. A. (2012). A Common Beta Tubulin Isotype-1 Gene Single Nucleotide Polymorphism as a Tool for Detection and Quantitation of Anthelmintic Resistant Haemonchus contortus in Grazing Goats. Journal of Agricultural Science, 4 (No. 6., June), 1-11. http://dx.doi.org/10.5539/jas.v4n7p31 
Corley, M. M., \& Jarmon, A. A. (2012). Interleukin 13 as a Biomarker for Parasite Resistance in Goats Naturally Exposed to Haemonchus contortus. Journal of Agricultural Science, 4(7), 31-40.

Corwin, R. M. (1997). Economics of gastrointestinal parasitism of cattle. Vet Parasitol, 72(3-4), 451-457; discussion 457-460. http://dx.doi.org/10.1016/S0304-4017(97)00110-6

Freichel, M., Vennekens, R., Olausson, J., Stolz, S., Philipp, S. E., Weissgerber, P., \& Flockerzi, V. (2005). Functional role of TRPC proteins in native systems: implications from knockout and knock-down studies. $J$ Physiol, 567(Pt 1), 59-66. http://dx.doi.org/10.1113/jphysiol.2005.092999

Gauthier, E. R., Madison, S. D., \& Michel, R. N. (1997). Rapid RNA isolation without the use of commercial kits: application to small tissue samples. Pflugers Arch, 433(5), 664-668. http://dx.doi.org/10.1007/s004240050328

Gonzalez-Cobos, J. C., \& Trebak, M. (2010). TRPC channels in smooth muscle cells. Front Biosci, 15, $1023-1039$. http://dx.doi.org/10.2741/3660

Grencis, R. K., \& Bancroft, A. J. (2004). Interleukin-13: a key mediator in resistance to gastrointestinal-dwelling nematode parasites. Clin Rev Allergy Immunol, 26(1), 51-60. http://dx.doi.org/10.1385/CRIAI:26:1:51

Hasnain, S. Z., Evans, C. M., Roy, M., Gallagher, A. L., Kindrachuk, K. N., Barron, L., . . Thornton, D. J. (2011). Muc5ac: a critical component mediating the rejection of enteric nematodes. $J$ Exp Med, 208(5), 893-900. http://dx.doi.org/10.1084/jem.20102057

Hogg, R., Whitaker, K., Collins, R., Holmes, P., Mitchell, S., Anscombe, J., . . Gilleard, J. (2010). Haemonchosis in large ruminants in the UK. Vet Rec, 166(12), 373-374. http://dx.doi.org/10.1136/vr.c1509

Holzer, P. (2011). Transient receptor potential (TRP) channels as drug targets for diseases of the digestive system. Pharmacol Ther, 131(1), 142-170. http://dx.doi.org/10.1016/j.pharmthera.2011.03.006

Kaplan, R. M., Burke, J. M., Terrill, T. H., Miller, J. E., Getz, W. R., Mobini, S., . . Vatta, A. F. (2004). Validation of the FAMACHA eye color chart for detecting clinical anemia in sheep and goats on farms in the southern United States. Vet Parasitol, 123(1-2), 105-120. http://dx.doi.org/10.1016/j.vetpar.2004.06.005

Khan, W. I., Richard, M., Akiho, H., Blennerhasset, P. A., Humphreys, N. E., Grencis, R. K., . . Collins, S. M. (2003). Modulation of intestinal muscle contraction by interleukin-9 (IL-9) or IL-9 neutralization: correlation with worm expulsion in murine nematode infections. Infect Immun, 71(5), 2430-2438. http://dx.doi.org/10.1128/IAI.71.5.2430-2438.2003

Kim, B. J., So, I., \& Kim, K. W. (2006). The relationship of TRP channels to the pacemaker activity of interstitial cells of Cajal in the gastrointestinal tract. $J$ Smooth Muscle Res, 42(1), 1-7. http://dx.doi.org/10.1540/jsmr.42.1

Le Jambre, L. F. (1995). Relationship of blood loss to worm numbers, biomass and egg production in Haemonchus infected sheep. Int J Parasitol, 25(3), 269-273. http://dx.doi.org/10.1016/0020-7519(94)00118-8

Lindsey, S. H., Tribe, R. M., \& Songu-Mize, E. (2008). Cyclic stretch decreases TRPC4 protein and capacitative calcium entry in rat vascular smooth muscle cells. Life Sci, 83(1-2), 29-34. http://dx.doi.org/10.1016/j.lfs.2008.04.013

Nilius, B., Voets, T., \& Peters, J. (2005). TRP channels in disease. Sci STKE, 2005(295), re8.

Patel, A., Sharif-Naeini, R., Folgering, J. R., Bichet, D., Duprat, F., \& Honoré, E. (2010). Canonical TRP channels and mechanotransduction: from physiology to disease states. Pflugers Arch, 460(3), 571-581. http://dx.doi.org/10.1007/s00424-010-0847-8

Perrigoue, J. G., Zaph, C., Guild, K., Du, Y., \& Artis, D. (2009). IL-31-IL-31R interactions limit the magnitude of Th2 cytokine-dependent immunity and inflammation following intestinal helminth infection. J Immunol, 182(10), 6088-6094. http://dx.doi.org/10.4049/jimmunol.0802459

Schillhorn van Veen, T. W. (1978). Haemonchosis in sheep during the dry season in the Nigerian savanna. Vet Rec, 102(16), 364-365. http://dx.doi.org/10.1136/vr.102.16.364

Terrill, T. H., Miller, J. E., Burke, J. M., Mosjidis, J. A., \& Kaplan, R. M. (2011). Experiences with integrated concepts for the control of Haemonchus contortus in sheep and goats in the United States. Vet Parasitol.

Tsvilovskyy, V. V., Zholos, A. V., Aberle, T., Philipp, S. E., Dietrich, A., Zhu, M. X., . . Flockerzi, V. (2009). Deletion of TRPC4 and TRPC6 in mice impairs smooth muscle contraction and intestinal motility in vivo. Gastroenterology, 137(4), 1415-1424. http://dx.doi.org/10.1053/j.gastro.2009.06.046 
Unno, T., Matsuyama, H., Okamoto, H., Sakamoto, T., Yamamoto, M., Tanahashi, Y., . . Komori, S. (2006). Muscarinic cationic current in gastrointestinal smooth muscles: signal transduction and role in contraction. Auton Autacoid Pharmacol, 26(3), 203-217. http://dx.doi.org/10.1111/j.1474-8673.2006.00366.x

Vallance, B. A., Blennerhassett, P. A., Deng, Y., Matthaei, K. I., Young, I. G., \& Collins, S. M. (1999). IL-5 contributes to worm expulsion and muscle hypercontractility in a primary T. spiralis infection. Am J Physiol, 277(2 Pt 1), G400-408.

van Dijk, J., \& Morgan, E. (2006). Haemonchosis on organic farms. Vet Rec, 159(19), 642. http://dx.doi.org/10.1136/vr.159.19.642

\section{Copyrights}

Copyright for this article is retained by the author(s), with first publication rights granted to the journal.

This is an open-access article distributed under the terms and conditions of the Creative Commons Attribution license (http://creativecommons.org/licenses/by/3.0/). 